\title{
Hydrochemistry and quality assessment of groundwater in the Ardabil area, Iran
}

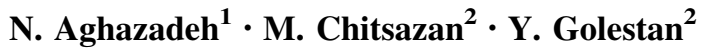

Received: 23 April 2016/Accepted: 8 November 2016/Published online: 19 November 2016

(c) The Author(s) 2016. This article is published with open access at Springerlink.com

\begin{abstract}
In the study area, groundwater is the main water resource for various purposes such as drinking, agriculture and industrial. To evaluate the hydrochemical characteristics of groundwater and suitability for drinking, irrigation and industrial purposes, seventy-seven samples were collected and analyzed for various ions. Results show that, groundwater in the study area is mainly hard to very hard, and slightly alkaline-fresh to brackish in nature. According to the hydrochemistry diagrams, the main groundwater types are $\mathrm{Ca}, \mathrm{Mg}-\mathrm{HCO}_{3}, \mathrm{Na}-\mathrm{HCO}_{3}$ and $\mathrm{Na}-\mathrm{Cl}$. Calculation of mineral saturation index indicate that the groundwater samples are saturated with respect to carbonate minerals and under-saturated with respect to sulfate minerals such as gypsum and anhydride. The mineral weathering, mixing, ion exchange and anthropogenic activity are the dominant hydrogeochemical natural processes. Results of investigating the quality of heavy metals and calculating the heavy metal index indicated that the groundwater of study area is not contaminated with heavy metals. In this research, the various indices were used to determine the quality of groundwater for various uses. Calculate the indices and comparison results with the WHO standards to determine the quality of groundwater for various uses indicated that the most of the groundwater in study area is chemically suitable for drinking, industrial and agricultural uses.
\end{abstract}

N. Aghazadeh

nosrataghazadeh@Yahoo.com; n.aghazadeh@iaurmia.ac.ir

1 Department of Geology, Urmia Branch, Islamic Azad University, Urmia 57159-44867, Iran

2 Department of Geology, Shahid Chamran University, Ahvaz, Iran
Keywords Ardabil · Groundwater quality · Heavy metals · Hydrochemistry · Hydrogeochemical processes

\section{Introduction}

Groundwater is the major source of water for domestic, agricultural and industrial purposes in many countries. The rapid increase in the population of the country has led to large scale groundwater developments in some areas. Intensive cultivating and urban development has caused a high demand on groundwater resources in arid and semiarid regions of the world and Iran, while putting these resources at greater risk to contamination (Asghari Moghaddam and Najib 2006; Khazaei et al. 2006; Jalali 2007; Giridharan et al. 2008; Aghazadeh and Mogaddam 2010; Esmaeili et al. 2015; Li 2016). The evaluation and management of groundwater resources require an understanding of hydrogeological and hydrogeochemical properties of the aquifer (Umar et al. 2001). Hydrogeochemical processes that are responsible for altering the chemical composition of groundwater vary with respect to space and time.

Chemical characteristics of groundwater play an important role in assessing and classifying the quality of water. Groundwater quality depends on a number of factors such as geology, degree of chemical weathering of the various rock types, quality of recharge water, and waterrock interaction (Domenico and Schwartz 1990; Guler and Thyne 2004; Ayenew et al. 2008; Giridharan et al. 2008; Aly 2015).

During the past decade, various geochemical methods have been successfully used to assess groundwater quality in world and Iran (e.g., Pazand and Javanshir 2014; Barzegar et al. 2016; Fijani et al. 2016; Kavurmac and 
Ustun 2016). Additionally, numerous recent studies have focused on analyzing the natural concentrations of several ions and metals in groundwater, to isolate anthropogenic and natural sources that affect groundwater quality, and establish interactions that take place within the aquifer (e.g., Aghazadeh and Mogaddam 2010; Jacintha et al. 2016; Ehya and Marbouti 2016; Sethy et al. 2016). A large number of groundwater studies also have focused specifically on the assessments of its suitability for drinking and irrigation purposes (Subramani et al. 2005; Kord et al. 2013; Sarikhani et al. 2015; Cao et al. 2016; Golchin and Azhdary Moghaddam 2016).

Groundwater is an important water resource for drinking, agriculture and industrial uses in Ardabil, a city in northwest of Iran. In study area, agriculture is the most important economic activity affecting the changes in groundwater quality by anthropogenic activity. However, in this area, quality assessment of groundwater has received little attention and efforts to use hydrochemical data to solve particular problems are less or nonexistent. Therefore, hydrochemical analysis of the groundwater has become a high priority concern.

Thus main objectives of the present study is (1) to identify the major hydrogeochemical processes (2) to determine the groundwater quality and (3) to delineate regions where groundwater is suitable or unsuitable for drinking, irrigation and industrial purpose.

\section{Description of the study area}

The study area is part of Ardabil province in northwest of Iran and located between the latitudes of $38^{\circ} 2^{\prime}$ to $38^{\circ} 27^{\prime} \mathrm{N}$ and longitudes of $48^{\circ} 6^{\prime}$, to $48^{\circ} 39^{\prime} \mathrm{E}$ (Fig. 1). Ardabil plain covers an area of $893 \mathrm{~km}^{2}$ with average altitude of 1400 m.a.s.l. The climate of study area is cold and semi arid. The air temperature is highest in August $\left(25.4^{\circ} \mathrm{C}\right)$ and lowest in February $\left(-6.9^{\circ} \mathrm{C}\right)$ with an annual average of 9.5 ${ }^{\circ} \mathrm{C}$. According to the data between 1990 and 2010 recorded at the Ardabil meteorological gauging station, the average annual precipitation is $286.3 \mathrm{~mm}$. About $65 \%$ of the annual precipitation falls between December and May, including a snowy period from November to March.

The main surface drainages are the Gharehso River and Balikhlichai River, which extends across the entire length of the Ardabil Plain. The average discharge of the Gharehso River is $7.9 \mathrm{~m}^{3} / \mathrm{s}$, with a maximum discharge of $15.6 \mathrm{~m}^{3} / \mathrm{s}$ (Ardabil Regional Water Authority (ARWA) 2014). The land use and land cover analysis show that agriculture land is the dominant land use category and comprises $80 \%$ of the total land (Kord et al. 2013). The most important economic activity of the area is agriculture and the chief crops are wheat, potatoes, barley, corn, sugar beet, and beans.
Base geological structural deviations of Iran, the investigated area is located in the Alborz-Azerbaijan zone of Iran and it is covered by Jurassic to Quaternary sediments (Nabavi 1976). The exposed lithological units of the Ardabil plain range in age from Jurassic to Quaternary (Fig. 2). Jurassic formations in the study area chiefly comprise alternation of shale, sandstone, marl and siltstone with intercalation of limestone. Crystallized thick bedded limestone with alternation of tuffaceous sandstone is cretaceous formation in study area. Trachyandesite, lapillus, tuff, volcanic breccias and granodiorite igneous rocks of Tertiary age are outcropped in many mountainous areas. Quaternary volcanic rocks in the study area were related to Sabalan volcanic activity and which mainly consists of lava andesitic and basalt. As a consequence, the Quaternary deposits are mainly characterized by clay, silted gravel with medium grained.

The result obtained from well logs, indicates that in Ardabil plain aquifer is unconfined and the thickness of the alluvium aquifer in average is $65 \mathrm{~m}$ (Ardabil Regional Water Authority (ARWA) 2014). The maximum thickness is about $220 \mathrm{~m}$, which lies in the east and central part of the plain. The general groundwater flow direction in the aquifer is from $\mathrm{S}, \mathrm{SE}$ to $\mathrm{NW}$, and its depth to water table varies from 0.5 to $56 \mathrm{~m}$ below the ground level. Abstraction rate from the aquifer during the water year 2009-2010 is about 219.3 million cubic meters. Eightyfive percent of exploited groundwater is used for agriculture, $14 \%$ for drinking and $1 \%$ is used by the industry. In study area, the maximum and minimum water level is in May and September, respectively (Ardabil Regional Water Authority (ARWA) 2014). The average fall of groundwater level in the last 30 years in the Ardabil aquifer is about $0.32 \mathrm{~m}$ (Ardabil Regional Water Authority (ARWA) 2014), that the reason is intense over-pumping and rapid development of agriculture and industry.

\section{Materials and methods}

In this research to evaluate the quality of groundwater, 77 groundwater samples were collected from shallow and deep wells and springs of the area during September 2010. Groundwater samples were analyzed for various chemical parameters as described by the American Public Health Association (APHA 1995). These parameters include hydrogen ion concentration $(\mathrm{pH})$, electrical conductivity (EC), total hardness (TH), total alkalinity (TA), total dissolved solids (TDS), and important cations such as calcium $\left(\mathrm{Ca}^{2+}\right)$, magnesium $\left(\mathrm{Mg}^{2+}\right)$, sodium $\left(\mathrm{Na}^{+}\right)$, potassium $\left(\mathrm{K}^{+}\right)$and iron $\left(\mathrm{Fe}^{2+}\right)$ as well as anions such as carbonates $\left(\mathrm{CO}_{3}{ }^{2-}\right)$, bicarbonates $\left(\mathrm{HCO}_{3}{ }^{-}\right)$, chlorides $\left(\mathrm{Cl}^{-}\right)$, nitrates $\left(\mathrm{NO}_{3}{ }^{-}\right)$, Phosphate $\left(\mathrm{PO}_{4}{ }^{3-}\right)$, sulfates $\left(\mathrm{SO}_{4}{ }^{2-}\right)$ and heavy 


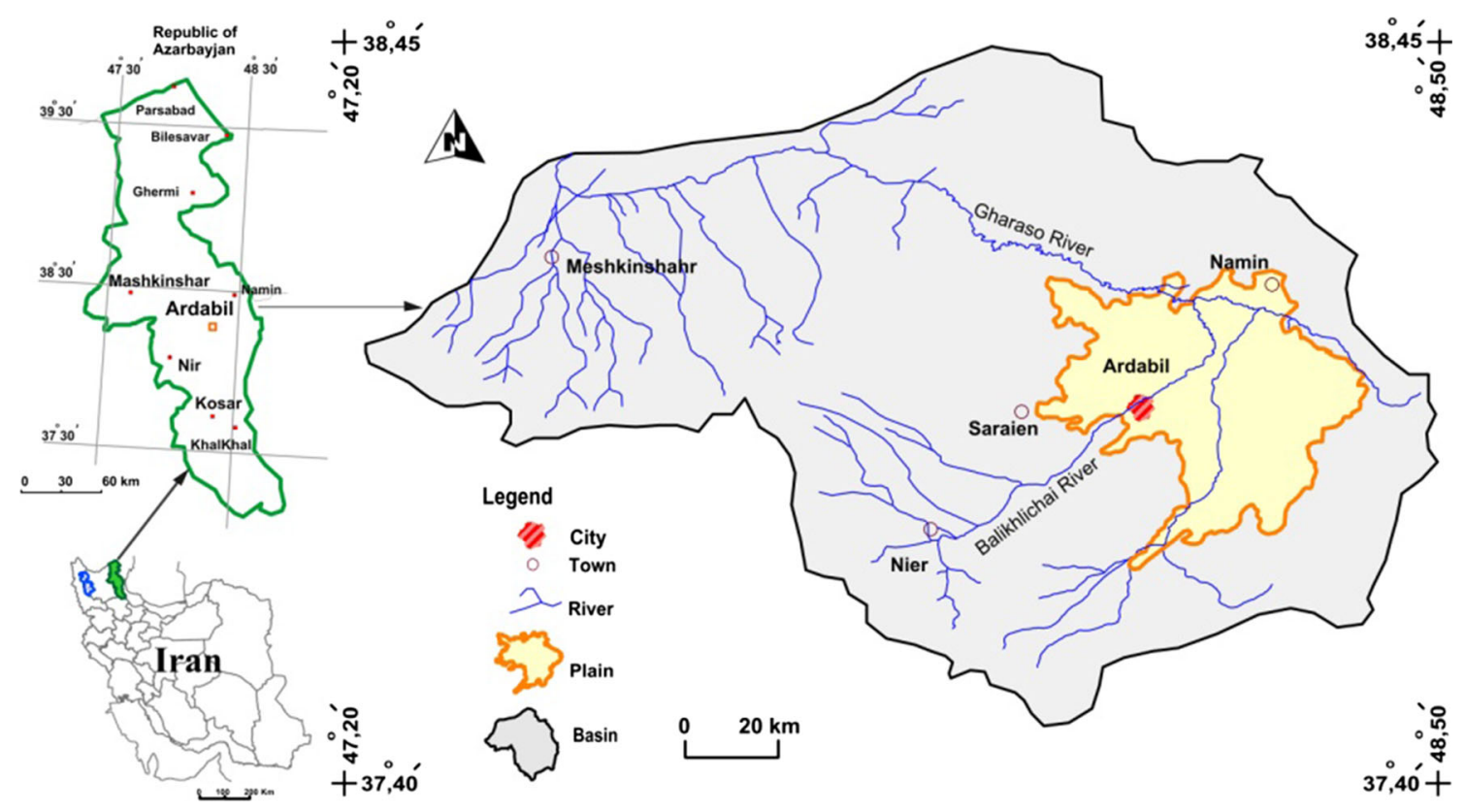

Fig. 1 Location map of study area and drainage pattern



Fig. 2 Geology map of study area and groundwater sample points 
metals (As, $\mathrm{Cu}, \mathrm{Cr}, \mathrm{Ni}, \mathrm{Zn}, \mathrm{Mn}, \mathrm{Hg}$ ). The $\mathrm{pH}$ and electrical conductivity (EC) were measured in field using portable conductivity meters. $\mathrm{Na}^{+}$and $\mathrm{K}^{+}$were determined by flame photometer. $\mathrm{Fe}^{2+}, \mathrm{PO}_{4}{ }^{3-}, \mathrm{NO}_{3}{ }^{-}$and $\mathrm{SO}_{4}{ }^{2-}$ were analyzed by spectrophotometer. TH and TA as $\mathrm{CaCO}_{3}$, $\mathrm{Ca}^{2+}, \mathrm{CO}_{3}{ }^{2-}, \mathrm{HCO}_{3}{ }^{-}$and $\mathrm{Cl}^{-}$were analyzed by volumetric method. $\mathrm{Mg}^{2+}$ was calculated from $\mathrm{TH}$ and $\mathrm{Ca}^{2+}$ contents. Heavy metals were analyzed by ICP-Mass methods. Based on the physico-chemical analyses, some important parameters and indices were calculated. Isoconcentration maps were constructed using the Arc GIS software. Saturation indices for carbonate and sulfate minerals and chemical facies were also computed through the computer programmers, PHREEQC and AQUCHEM. The correlation of the analytical data has been attempted by plotting different graphical representation for the classification of water and to study the suitability of groundwater for utilitarian purposes by ascertaining various factors on which the chemical characteristics of water depend. The suitability of the groundwater for drinking, industrial, domestic, and irrigation purposes was evaluated by comparing the values of different water quality parameters with those of the World Health Organization (WHO 2004) guideline values for drinking water.

\section{Results and discussion}

\section{Chemical characteristics of groundwater}

The $\mathrm{pH}$ in groundwater samples varied from 6.37 to 8.14 that indicating slightly acidic to slightly basic in nature. In the study area, the electrical conductivity (EC) of groundwater varies widely between 366 and $4981 \mu \mathrm{S} / \mathrm{cm}$. In $52 \%$ of the groundwater samples the enrichments of salts are low $(\mathrm{EC}<1500 \mu \mathrm{S} / \mathrm{cm}), 43 \%$ of samples are medium (EC: 1500 and $3000 \mu \mathrm{S} / \mathrm{cm}$ ) and $5 \%$ of samples are high $(\mathrm{EC}>3000 \mu \mathrm{S} / \mathrm{cm})$. Higher value of EC can be due to the dissolution of minerals and the influence of anthropogenic contamination, causing increases in ionic concentration. Total dissolved solids (TDS) in the study area vary from 92 to $4508 \mathrm{mg} / \mathrm{l} \mathrm{L}$ and groundwater is generally fresh to brackish in nature.

Large variations in EC and TDS values are primarily attributed to geochemical process like ion exchange, evaporation, sediment dissolution, and rainwater infiltration (Ehya and Marbouti 2016) and anthropogenic sources (such as domestic sewage, septic tanks, and agricultural activities) (Hosseinifard and Mirzaei Aminiyan 2015).

The value of total alkalinity (TA) is observed from 78 to $774 \mathrm{mg} / \mathrm{L}$ (Table 1) that, it is caused by $\mathrm{HCO}_{3}{ }^{-}$ion only, as the $\mathrm{pH}$ is between 6.37 and 8.14. This alkalinity also suggests that dissolution has been occurred due to interaction between soil and rainwater, giving groundwater alkaline character (Singh et al. 2012).

The $\mathrm{TH}\left(\mathrm{as}_{\mathrm{CaCO}}\right)$ in the groundwater of study area is between 49 and $1519 \mathrm{mg} / \mathrm{L}$. According to the classification of $\mathrm{TH}$, approximately $2 \%$ of the groundwater samples come under the fresh, $10 \%$ are moderately hard category, $23 \%$ of the groundwater samples come under the hard category and the remaining $66 \%$ of the groundwater samples fall in the very hard category. Cation concentrations and ratios can trace water-rock interaction processes, such as mineral weathering and cation exchange (Han et al. 2009). The concentrations of calcium range from 12.5 to $404 \mathrm{mg} / \mathrm{l}$ (Fig. 3a; Table 1), which is derived from calcium rich minerals like feldspars, pyroxenes and amphiboles. The major source of magnesium $\left(\mathrm{Mg}^{2+}\right)$ in the groundwater is due to ion exchange of minerals in rocks and soils by water. The concentrations of $\mathrm{Mg}^{2+}$ found in the groundwater samples vary in the range $1.4-121.7 \mathrm{mg} / \mathrm{l}$ (Fig. 3b; Table 1).

In the study area, the $\mathrm{Na}^{+}$and $\mathrm{K}^{+}$concentrations in groundwater range from 6.2 to 399 and 0.4 to $138 \mathrm{mg} / \mathrm{l}$, respectively (Fig. 3c; Table 1). High concentrations of $\mathrm{Na}^{+}$in the groundwater are attributed to cation exchange among minerals, anthropogenic activities (spatial agricultural activities) and poor drainage conditions.

The carbonate and bicarbonate concentration in groundwater is derived from carbonate weathering, as well as dissolution of carbonic acid in the aquifers (Kumar et al. 2009) (Eq. 1).

$$
\begin{aligned}
\mathrm{CaCO}_{3}+\mathrm{CO}_{2}+\mathrm{H}_{2} \mathrm{O} & \rightarrow \mathrm{Ca}^{2+}+2 \mathrm{HCO}_{3}^{-} \text {and } \mathrm{CO}_{2}+\mathrm{H}_{2} \mathrm{O} \\
& \rightarrow \mathrm{H}^{+}+\mathrm{HCO}_{3}^{-} .
\end{aligned}
$$

The value of $\mathrm{HCO}_{3}{ }^{-}$is observed from 96 to $945 \mathrm{mg} / \mathrm{L}$, which is the dominant ion in some of the groundwater (Fig. 3d; Table 1). The higher concentration of $\mathrm{HCO}_{3}{ }^{-}$in the water infers a dominance of mineral dissolution. The carbonates available in carbonate rocks could have been dissolved during irrigation, rainfall infiltration and groundwater movement, and added to the groundwater system with recharging water (Singh et al. 2012). The concentration of chloride ranges from 9 to $667 \mathrm{mg} / \mathrm{l}$ and increases from the recharge to discharge area and is dominant anion in some of the samples (Fig. 3e; Table 1). Sulfate varies from 4.2 to $1286 \mathrm{mg} / \mathrm{l}$ (Fig. 3f; Table 1). The abundance of the major ions in groundwater is in following order $\mathrm{Ca}^{2+}, \mathrm{Na}^{+}>\mathrm{Mg}^{2+}>\mathrm{K}^{+}$and $\mathrm{HCO}_{3}{ }^{-}$ $\mathrm{SO}_{4}{ }^{2-}>\mathrm{Cl}^{-}>\mathrm{CO}_{3}{ }^{2-}$. Minimum, maximum and average values of physical and chemical parameters of groundwater samples are presented in Table 1.

The concentration of nitrate $\left(\mathrm{NO}_{3}{ }^{-}\right)$in the study area varies from 2.26 to $130 \mathrm{mg} / \mathrm{l}$ with an average value of 
Table 1 Summary statistics of the analytical data in study area

\begin{tabular}{|c|c|c|c|c|c|c|c|}
\hline Parameters & Units & Minimum & Maximum & Mean & Standard deviation & $\begin{array}{l}\text { Most desirable limits } \\
\text { (WHO 2004) }\end{array}$ & $\begin{array}{l}\text { Maximum allowable } \\
\text { limits (WHO 2004) }\end{array}$ \\
\hline $\mathrm{pH}$ & - & 6.37 & 8.14 & 7.37 & 0.36 & 5 & 8.5 \\
\hline $\mathrm{EC}$ & $\mu \mathrm{moh} / \mathrm{cm}$ & 366 & 4981 & 1424 & 830 & 1400 & - \\
\hline TDS & $\mathrm{mg} / \mathrm{l}$ & 92 & 4508 & 918.6 & 705 & 500 & 1500 \\
\hline $\mathrm{Na}$ & $\mathrm{mg} / \mathrm{l}$ & 6.2 & 399.2 & 131.5 & 89.9 & - & 200 \\
\hline $\mathrm{K}$ & $\mathrm{mg} / \mathrm{l}$ & 0.4 & 138.5 & 23.76 & 26 & - & 20 \\
\hline $\mathrm{Ca}$ & $\mathrm{mg} / \mathrm{l}$ & 12.5 & 404.6 & 112. 6 & 88.6 & 75 & 200 \\
\hline $\mathrm{Mg}$ & $\mathrm{mg} / \mathrm{l}$ & 1.4 & 121.7 & 42.3 & 24.36 & 50 & 150 \\
\hline $\mathrm{Cl}$ & $\mathrm{mg} / \mathrm{l}$ & 8.9 & 667.4 & 161.3 & 134.5 & 200 & 600 \\
\hline $\mathrm{HCO}_{3}$ & $\mathrm{mg} / \mathrm{l}$ & 95.6 & 945.3 & 381.23 & 190.3 & - & 300 \\
\hline $\mathrm{SO}_{4}$ & $\mathrm{mg} / \mathrm{l}$ & 4.2 & 1286 & 273.4 & 224 & 299 & 400 \\
\hline $\mathrm{PO}_{4}$ & $\mathrm{mg} / \mathrm{l}$ & 0 & 1.72 & 0.35 & 0.4 & - & 250 \\
\hline $\mathrm{NO}_{3}$ & $\mathrm{mg} / \mathrm{l}$ & 0 & 130 & 26.5 & 24.7 & - & 50 \\
\hline $\mathrm{F}$ & $\mathrm{mg} / \mathrm{l}$ & 0.15 & 1.18 & 0.51 & 0.23 & - & 1.5 \\
\hline $\mathrm{Fe}$ & $\mathrm{g} / \mathrm{l} \mu$ & 0.95 & 181 & 29.7 & 29.3 & - & 300 \\
\hline $\mathrm{Mn}$ & $\mathrm{g} / 1 \mu$ & 0 & 16.43 & 5.5 & 4 & - & 500 \\
\hline $\mathrm{Cr}$ & $\mathrm{g} / 1 \mu$ & 0 & 12.8 & 0.53 & 1.5 & - & 50 \\
\hline As & $\mathrm{g} / \mathrm{l} \mu$ & 0 & 9.42 & 0.43 & 1.3 & - & 10 \\
\hline $\mathrm{Cu}$ & $\mathrm{g} / 1 \mu$ & 0 & 11.4 & 2.2 & 2.3 & - & 2000 \\
\hline $\mathrm{Hg}$ & $\mathrm{g} / \mathrm{l} \mu$ & 0 & 3.12 & 0.3 & 0.44 & - & 6 \\
\hline $\mathrm{TH}$ & $\mathrm{mg} / \mathrm{l}$ & 48.8 & 1518.58 & 457.95 & 292.77 & 100 & 500 \\
\hline TA & $\mathrm{mg} / \mathrm{l}$ & 78 & 774 & 312 & 156 & - & - \\
\hline SAR & - & 0.22 & 6.1 & 2.7 & 1.5 & - & - \\
\hline$\% \mathrm{Na}$ & $\%$ & 9 & 97.3 & 40.8 & 17.32 & - & - \\
\hline RSC & meq/l & -18.59 & 5.86 & -2.9 & 4.53 & - & - \\
\hline PI & $\%$ & 30.87 & 93 & 59 & 18.98 & - & - \\
\hline $\mathrm{SI}_{\text {calcite }}$ & - & -2.01 & 1.12 & -0.39 & 0.69 & - & - \\
\hline $\mathrm{SI}_{\text {dolomite }}$ & - & -5.62 & 1.29 & -1.59 & 1.36 & - & - \\
\hline $\mathrm{SI}_{\text {gypsum }}$ & - & -2.48 & -0.44 & -1.11 & 0.42 & - & - \\
\hline $\mathrm{SI}_{\text {anhydrate }}$ & - & -2.73 & -0.7 & -1.36 & 0.42 & - & - \\
\hline $\mathrm{SI}_{\text {aragonite }}$ & - & -2.17 & 0.96 & -0.54 & 0.68 & - & - \\
\hline
\end{tabular}

$E C$ electrical conductivity, TDS total dissolved solids, $T H$ total hardness, SAR sodium adsorption ratio, $R S C$ residual sodium carbonate, \% $N a$ sodium percent, $P I$ permeability index, SI saturation index

$26.4 \mathrm{mg} / \mathrm{l}$ (Table 1). Groundwater can be contaminated by fertilizer application, human and livestock sewage, deposition of plants and other wastes rich in nitrates (Chukwura et al. 2015; Vincy et al. 2015).

The nitrate concentration was relatively high in some of the groundwater samples. Spatial distribution of the nitrate concentration in the groundwater is illustrated in Fig. $3 \mathrm{~g}$. The concentration of nitrate was relatively high in around the Ardabil city, south and south-eastern parts of the study area. However, in most of the samples (88\%), the nitrate concentration was below the permissible drinking limits set by the WHO $(50 \mathrm{mg} / \mathrm{l})$. In the study area, agricultural activities are mainly dependent on the groundwater resources. A very high nitrate concentration is observed along the Balekhli River, which may be due to the seepage of irrigation waters from agricultural fields where chemical fertilizers are being used in discriminately (Kord et al. 2013). The high nitrate values in around the Ardabil city are attributed to the overflowing sewage water. In addition to this, phosphate concentrations were found to vary from 0.01 to $1.72 \mathrm{mg} / \mathrm{L}$ (Fig. 3h; Table 1).

Fluoride $\left(\mathrm{F}^{-}\right)$is one of the main trace elements in groundwater, which generally occurs as a natural constituent. The concentration of fluoride in groundwater in study area varied from 0.15 to $1.18 \mathrm{mg} / \mathrm{l}$ (Table 1), and the mean value was $0.5 \mathrm{mg} / \mathrm{l}$. Concentration of fluoride was low in the major part of the study area, which indicates limited lithogenic input of fluoride ion in groundwater samples. The spatial distribution of fluoride ion concentration in groundwater is illustrated in the Fig. 3i. The iron 

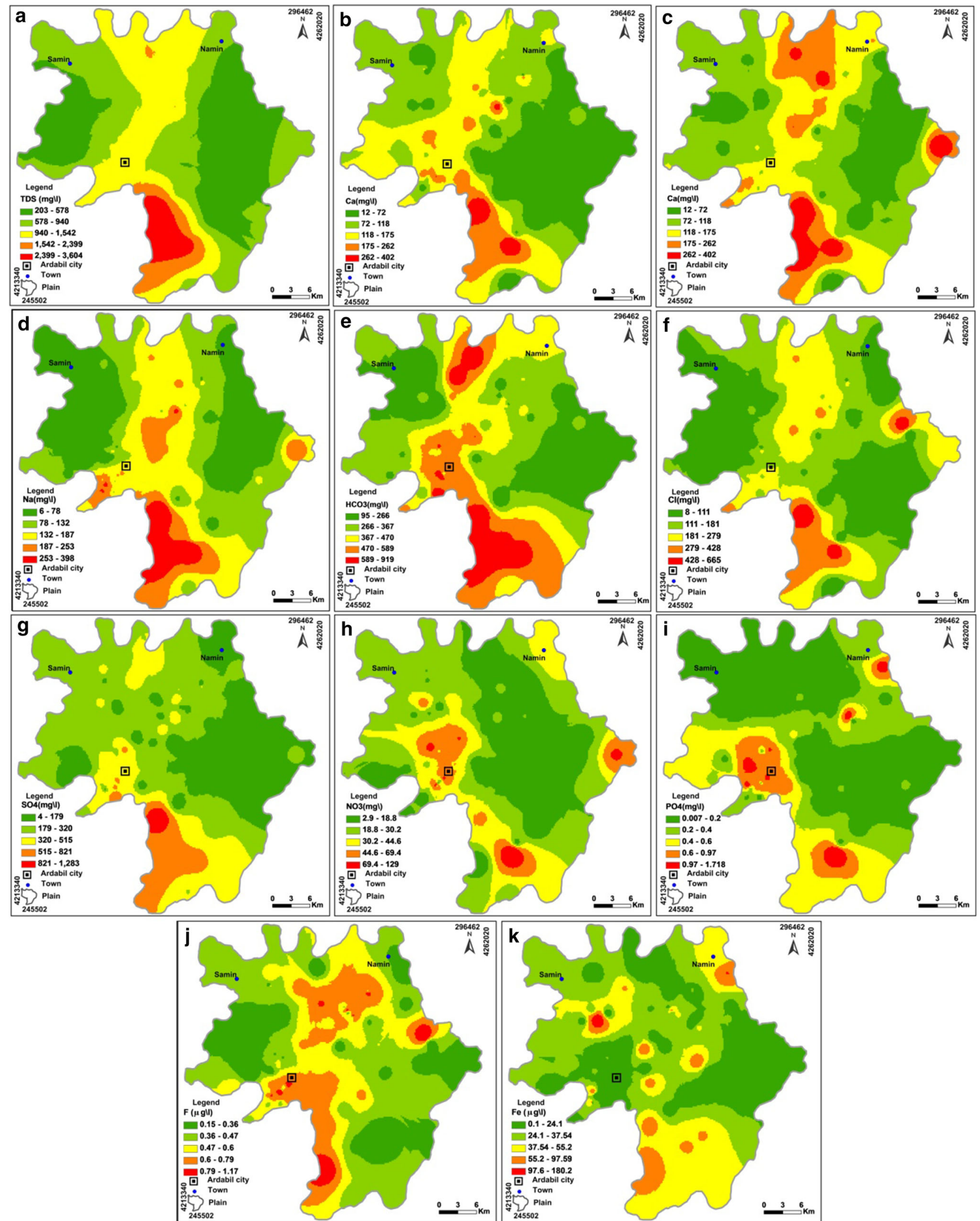

Fig. 3 Spatial Distribution of TDS, $\mathrm{Ca}, \mathrm{Mg}, \mathrm{Na}, \mathrm{HCO}_{3}, \mathrm{Cl}, \mathrm{SO}_{4}, \mathrm{NO}_{3}, \mathrm{PO}_{4}, \mathrm{~F}$ and $\mathrm{Fe}$ in the Ardabil area 

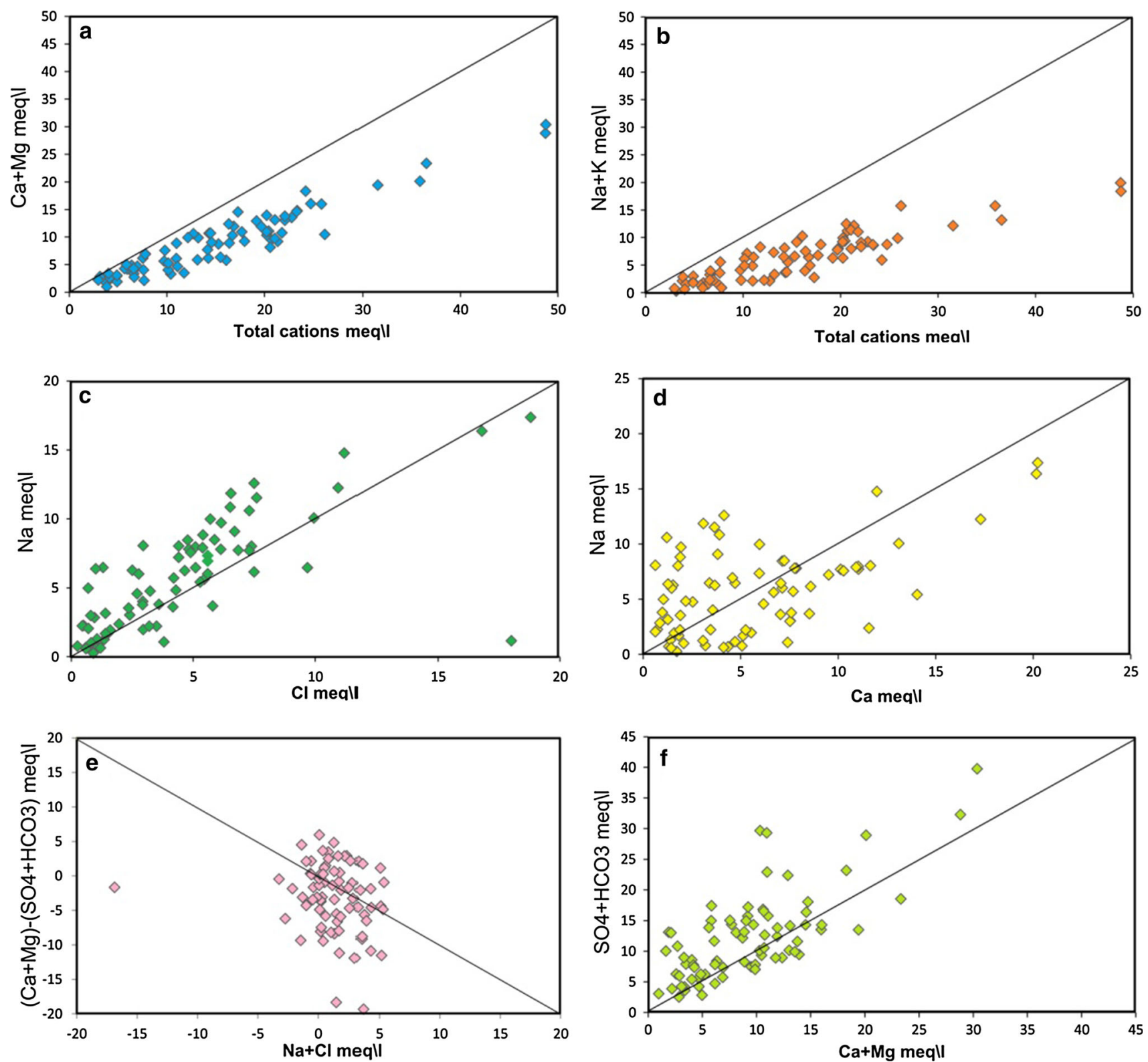

Fig. 4 Graphs of different parameters in groundwater of study area (solid line denotes 1:1)

concentration generally varies from 0.001 to $0.18 \mathrm{mg} / \mathrm{l}$ with an average concentration of $0.003 \mathrm{mg} / \mathrm{l}$ (Table 1). The high iron concentration is observed mainly in the northwest and also in the east parts of the study area. A very high concentration of iron in groundwater is found in northeast side villages of Barogh $(0.18 \mathrm{mg} / \mathrm{l})$. All the samples from study were within the prescribed standard desirable limit set by the WHO.

\section{Hydrochemical evaluation}

The major ion chemistry of groundwater is a powerful tool for determining solute sources and for describing groundwater evolution as a result of water-rock interaction leading to the dissolution of carbonate minerals, silicate weathering and ion exchange processes (Kumar et al. 2009). Results from the chemical analyses were used to identify the geochemical processes and mechanisms in the groundwater aquifer system. The chemical data of the groundwater samples is plotted for $\mathrm{Ca}^{2+}+\mathrm{Mg}^{2+}$ and $\mathrm{Na}^{+}+\mathrm{K}^{+}$vs. TC (total cation) (Fig. 4a, b). The graphs show that the most of the samples far below the theoretical line (1:1), indicating supply of cations via ion exchange, silicate weathering and/or soil salts is more significant.

High concentration of $\mathrm{Na}$ with respect to $\mathrm{Cl}$ or depletion of $\mathrm{Na}$ with respect to $\mathrm{Cl}$ is the evident of cation exchange reactions (Sethy et al. 2016). Result shows that, most of the samples have a $\mathrm{Na} / \mathrm{Cl}$ ratio around or above 1 , indicating 
Fig. 5 Mechanisms governing groundwater chemistry in Gibbs diagram



that an ion exchange process is prevalent in the study area (Fig. 4c). Also, Fig. 4d shows the ion exchange reactions, where $\mathrm{Na}^{+}$is plotted against $\mathrm{Ca}^{2+}$, in which $\mathrm{Ca}^{2+}$ levels are observed between 0.6 and $20 \mathrm{meq} / \mathrm{l}$, while $\mathrm{Na}^{+}$levels are found between 0.3 and $17.4 \mathrm{meq} / \mathrm{l}$. If the ion exchange is the only controlling process of groundwater composition, the relation between $\left(\mathrm{Ca}^{2+}+\mathrm{Mg}^{2+}\right)-\left(\mathrm{SO}_{4}{ }^{2-}+\mathrm{HCO}_{3}{ }^{-}\right)$ and $\mathrm{Na}^{+}-\mathrm{Cl}^{-}$should show negative linear trend with a slope of unity, considering the participation of cations in the ion exchange reaction (Fisher and Mullican 1997). In Fig. $4 \mathrm{e}$, the samples show a trend of $\left(\mathrm{Ca}^{2+}+\mathrm{Mg}^{2+}\right)$ $\left(\mathrm{SO}_{4}{ }^{2-}+\mathrm{HCO}_{3}{ }^{-}\right)$versus $\mathrm{Na}^{+}-\mathrm{Cl}^{-}$with a negative slope of less than unity, but they spread above and below the linear trend. This suggests that the controlling of groundwater quality depends not only on the involvement of ion exchange process, but also on the involvement of other processes. Otherwise, the spreading of sample points above and below the linear trend should not be expected. The graph of $\mathrm{Ca}^{2+}+\mathrm{Mg}^{2+}$ versus $\mathrm{SO}_{4}^{-2}+\mathrm{HCO}_{3}^{-}$will feature a nearly 1:1 line if dissolutions of calcite, dolomite and gypsum are the dominant reactions in the system (Srivastava and Ramanathan 2008; Fijani et al. 2016). Ion exchange tends to shift the points right because of the excess of $\mathrm{SO}_{4}{ }^{2-}+\mathrm{HCO}_{3}{ }^{-}$ions, which may be due to anthropogenic input in the groundwater system (Fisher and Mullican 1997; Barzegar et al. 2016). The graph of $\mathrm{Ca}^{2+}+\mathrm{Mg}^{2+}$ versus $\mathrm{SO}_{4}{ }^{2-}+\mathrm{HCO}_{3}{ }^{-}$(Fig. 4f) shows that most of samples fall above the 1:1 ratio line and show a deficiency of $\mathrm{Ca}^{2+}+\mathrm{Mg}^{2+}$ relative to $\mathrm{SO}_{4}{ }^{2-}+\mathrm{HCO}_{3}{ }^{-}$. Higher concentration of $\mathrm{Na}^{+}$in the groundwater is an index of ion exchange process. Also, the scatter diagram of $\mathrm{Ca}^{2+}+\mathrm{Mg}^{2+}$ versus $\mathrm{SO}_{4}{ }^{2-}+\mathrm{HCO}_{3}{ }^{-}$shows that silicate weathering was the primary process involved in the evolution of groundwater. If bicarbonate and sulfate are dominating than calcium and magnesium, it reflects that silicate weathering was dominating and, therefore, was responsible for the increase in the concentration of $\mathrm{HCO}_{3}$ in groundwater. The study of $\mathrm{Ca} / \mathrm{Mg}$ ratio also revealed that the dissolution of silicate minerals was one of the prime processes involved in attaining the present chemical makeup of the groundwater. The $\mathrm{Ca}^{2+} / \mathrm{Mg}^{2+}$ ratio of 1 indicated dissolution of dolomite and of $>2$ reflected an effect of silicate minerals on the groundwater chemistry; it also suggested dolomite dissolution for $\mathrm{Ca}^{2+}, \mathrm{Mg}^{2+}$ concentration in groundwater (Barzegar et al. 2016). Majority of the samples have $\mathrm{Ca}^{2+} / \mathrm{Mg}^{2+}$ ratio between 0.6 and 3.3, indicating effect of silicate minerals on the groundwater chemistry.

The chemical data of groundwater sample were plotted in Gibbs's diagrams (Gibbs 1970) (Fig. 5). The clustering of the data points in Gibbs diagram indicates that most of samples the chemical weathering of rock-forming minerals is influencing the groundwater quality and also in some of samples evaporation is influencing the groundwater quality.

\section{Hydrochemical facies and water type}

The hydrochemical facies reflect the effect of chemical processes in the lithological environment and the contained groundwater flow patterns (Back 1966; Freeze and Cherry 1979).

In this study, we used to Piper and Durov diagrams to determine the hydrochemical facies of groundwater. The values obtained from the groundwater sample analyzing, and their plot on the Piper's diagrams (1944) (Fig. 6) reveal that in the most samples no cation-anion exceed $50 \%$. However the major cations are $\mathrm{Ca}^{2+}, \mathrm{Na}^{+}$and the anion is $\mathrm{HCO}_{3}{ }^{-}, \mathrm{Cl}^{-}$. In the study area, $22 \%$ samples 
Fig. 6 Chemical facieses of groundwater in Piper diagram

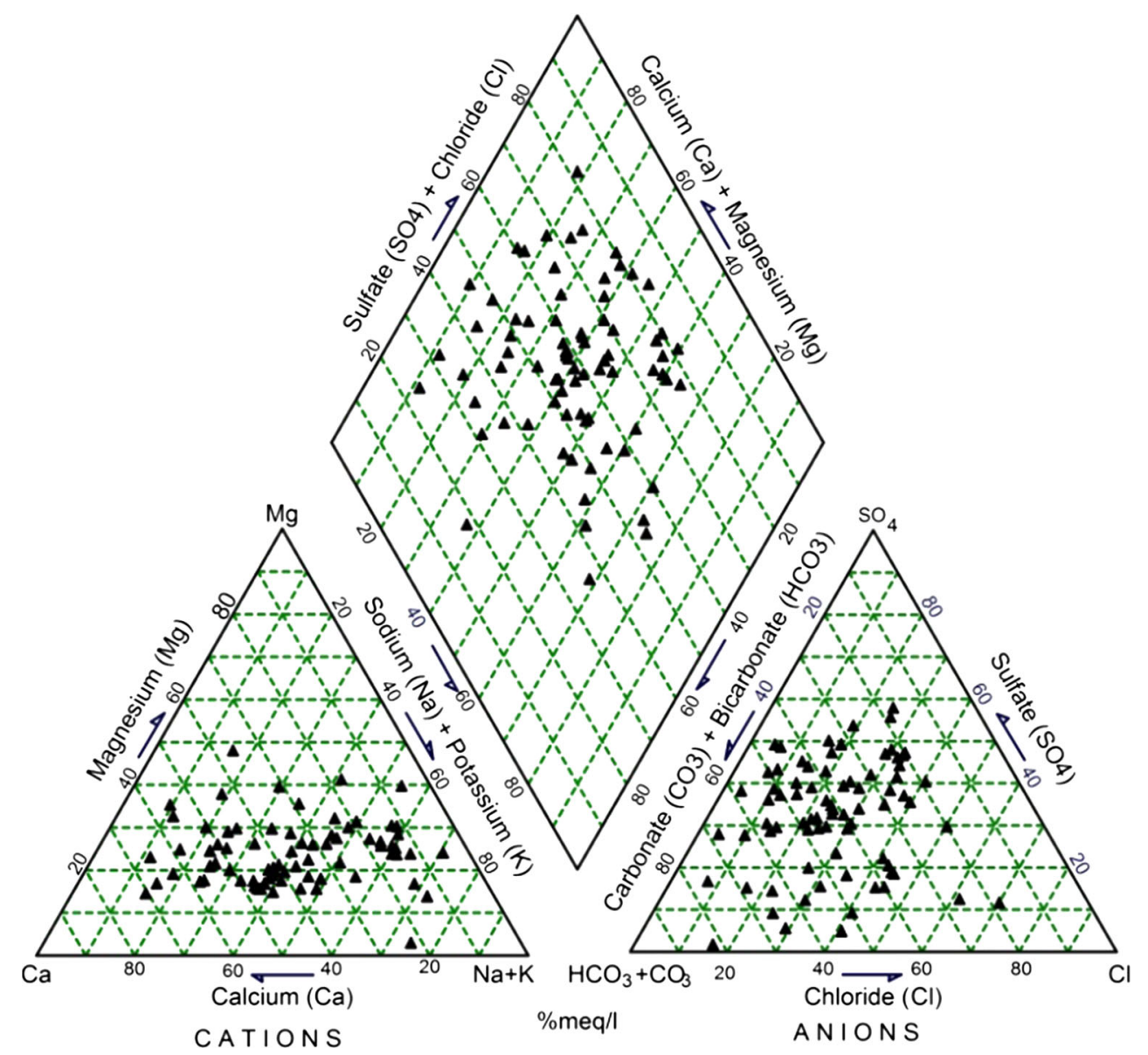

belong to the $\mathrm{Ca}, \mathrm{Mg}-\mathrm{HCO}_{3}, 53 \%$ of the samples belong to the $\mathrm{Na}-\mathrm{HCO}_{3}, 18 \%$ of the samples belong to the $\mathrm{Na}-\mathrm{Cl}$ and $7 \%$ of the samples belong to the mixed water types. The sodium-chloride water type in study area is due to the low velocity of groundwater, ion exchange, long time contacts of water and the type of the rocks.

To determine the domain hydrochemical processes and type of ion exchange chemical data of groundwater samples have been plotted on the Durov diagram (Durov 1948; Lloyd and Heathcode 1985). According to Durov diagram (Fig. 7) the majority of samples fell in mixed zone, indicating in the most samples none dominate cation-anion and the major hydrochemical processes are mixing and normal ion exchange.

\section{Saturation indices and water mineral equilibrium}

The equilibrium state of the water with respect to a mineral phase can be determined by calculating a saturation index (SI) using analytical data (Garrels and Mackenzie 1967). Changes in saturation state are useful to distinguish different stages of hydrochemical evolution and help identify which geochemical reactions are important in controlling water chemistry (Drever 1997; Langmuir 1997; Coetsiers and Walraevens 2006). The saturation index of a mineral is obtained from Eq. 2 (Garrels and Mackenzie 1967).

$\mathrm{SI}=\log \frac{\mathrm{IAP}}{\mathrm{KT}}$,

where IAP is the ion activity product of the dissociated chemical species in solution, $\mathrm{Kt}$ is the equilibrium solubility product for the chemical involved at the sample temperature.

The saturation indexes were determined using the hydrogeochemical equilibrium model, PHREEQC for Windows (Parkhurst and Appelo 1999).

An index (SI), less than zero, indicate that the groundwater is under-saturated with respect to that particular mineral. An index (SI), greater than zero, specifies that the groundwater being supersaturated with respect to the particular mineral phase and therefore incapable of dissolving more of the mineral. Such an index value reflects groundwater discharging from an aquifer containing ample amount of the mineral with sufficient resident time to reach equilibrium (Appelo and Postma 1996; Langmuir 1997). In Table 1 the SI for calcite, dolomite, anhydrate and gypsum are shown. The plot of saturation indices of calcite (SIC) 
Fig. 7 Chemical facieses of groundwater in Durov diagram

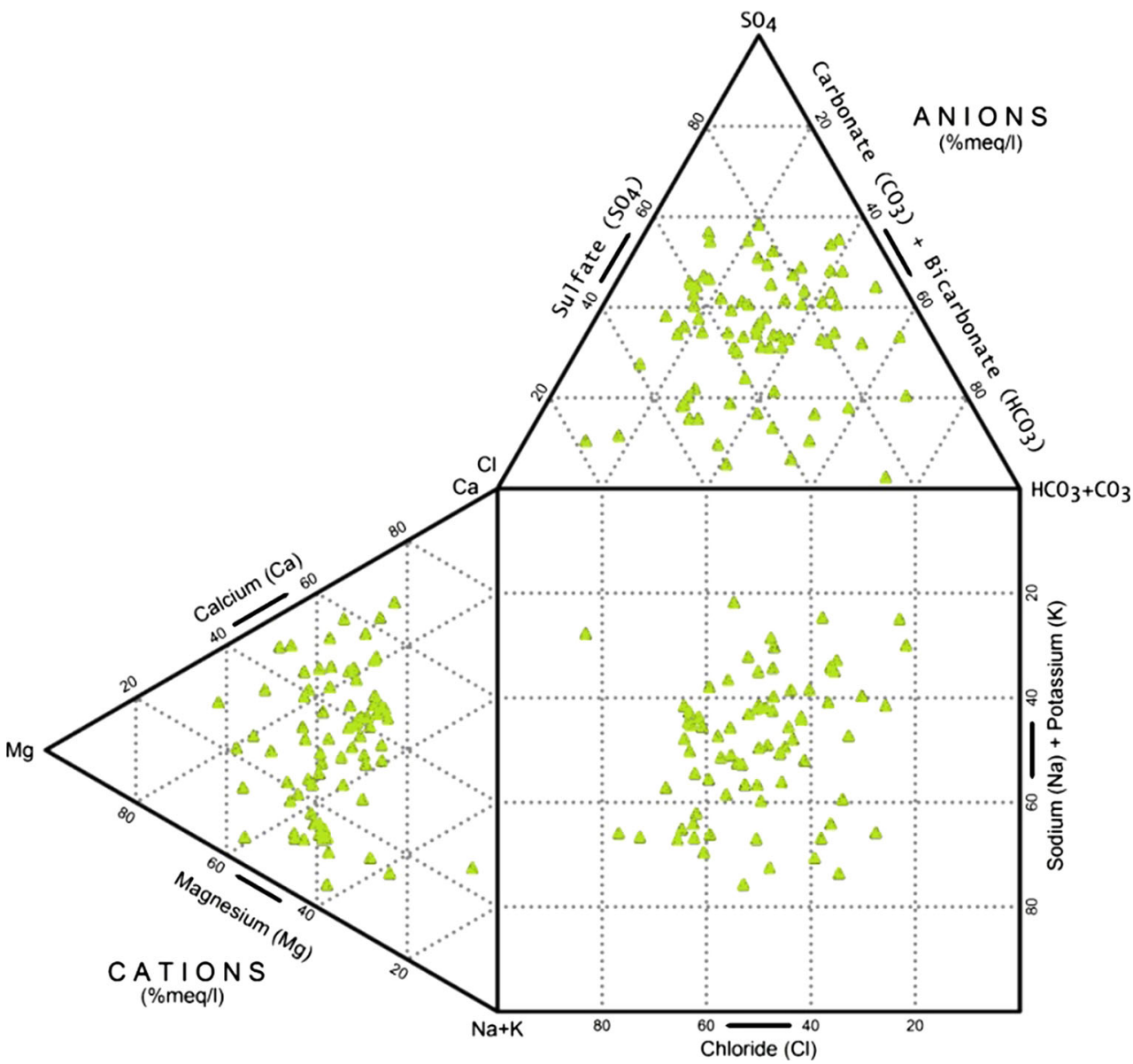

versus dolomite (SID) demonstrates that the $91 \%$ of the waters are under-saturated with respect to dolomite and $68 \%$ are under-saturated with respect to calcite (Fig. 8). The SID and SIC values are 1.29 to -5.62 and 1.12 to -2.01 , respectively. Figure 9 shows the plots of SI against TDS for all the investigated water. All of groundwater samples were under-saturated with respect to gypsum and anhydrite because the major lithological units of the around Ardabil plain are volcanic rocks and there are not insufficient evaporate minerals for solution.

\section{Heavy metals concentrations and classification of groundwater base heavy metal index}

The most common heavy metals of concern in water are chromium $(\mathrm{Cr})$, iron $(\mathrm{Fe})$, nickel $(\mathrm{Ni})$, and zinc $(\mathrm{Zn})$, copper $(\mathrm{Cu})$, lead $(\mathrm{Pb})$, arsenic $(\mathrm{As})$, mercury $(\mathrm{Hg})$ and cadmium $(\mathrm{Cd})$. Excess levels of these heavy metals can damage human health and ecosystems (Ehya and Marbouti 2016). The concentrations of heavy metals in groundwater samples from different location are given in Table 4, and compared with WHO standard (2004). Results of investigating the quality of heavy metals show that the abundance of the heavy metals in groundwater are in following order: $\mathrm{Fe}>\mathrm{Mn}>\mathrm{Zn}>\mathrm{Cu}>\mathrm{Cr}>$ $\mathrm{Ni}>\mathrm{As}>\mathrm{Hg}>\mathrm{Ce}$ (Table 1$)$.

The $\mathrm{Fe}$ and $\mathrm{Mn}$ in the groundwater of study area ranged from 0.95 to $181 \mu \mathrm{g} / \mathrm{l}$ with an average value of $29.7 \mu \mathrm{g} / \mathrm{l}$ and from 0 to $16.4 \mu \mathrm{g} / \mathrm{l}$ with an average value of $5.5 \mu \mathrm{g} / \mathrm{l}$, respectively. Chrome levels in the groundwater of study area ranged from 0 to $12.8 \mu \mathrm{g} / \mathrm{l}$, with an average of $0.53 \mu \mathrm{g} / \mathrm{l}$ (Table 1). The average Arsenic concentration in the groundwater was $0.4 \mu \mathrm{g} / \mathrm{l}$, with a range of $0-1.88 \mu \mathrm{g} / \mathrm{l}$ (Table 1). The $\mathrm{Cu}$ and $\mathrm{Hg}$ in the groundwater of study area ranged from 0 to $11.4 \mu \mathrm{g} / \mathrm{l}$ with an average value of $2.21 \mu \mathrm{g} / \mathrm{l}$ and from 0 to $3.12 \mu \mathrm{g} / \mathrm{l}$ with an average value of $0.29 \mu \mathrm{g} / \mathrm{l}$, respectively. The heavy metal concentrations sampled from the groundwater of study area are also compared with WHO Standard (2004) (Table 1). The result shows that almost in the all of samples concentrations of heavy metals are lower than the corresponding WHO values.

In this study, two heavy metal index (Heavy metal Pollution Index (HPI) developed by Prasad and Bose (2001) and the Heavy metal Evaluation Index (HEI) proposed by Edet and Offiong (2002) used to classify the groundwater. To calculate the HPI and HEI index the groundwater of study area, the concentration value of seven 
Fig. 8 Plot of saturation indices (SI) for calcite (SIC) versus dolomite (SID)
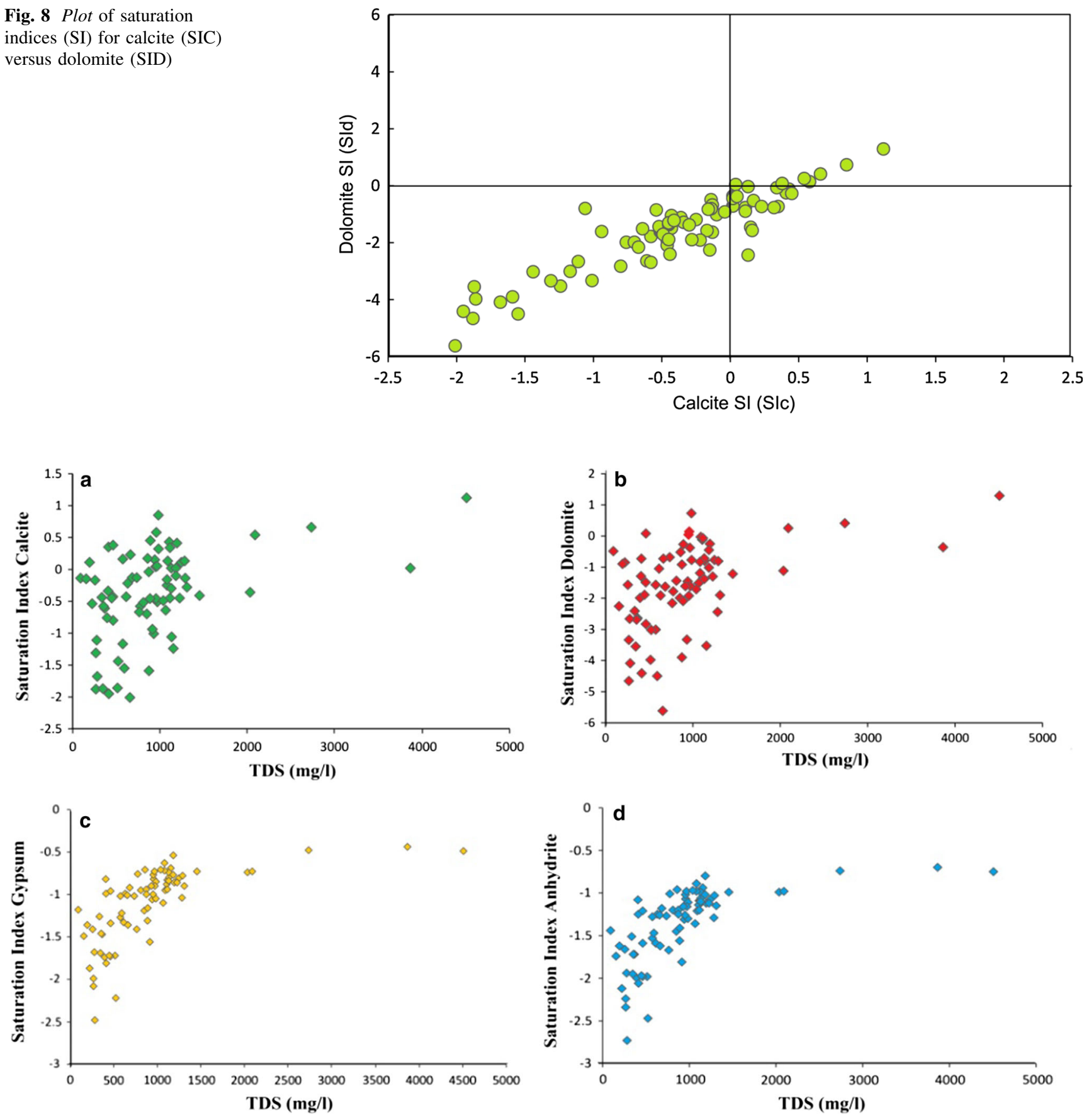

Fig. 9 Plot of saturation indices (SI) versus total dissolved solid (TDS)

heavy metals $(\mathrm{Cr}, \mathrm{Cu}, \mathrm{Zn}, \mathrm{Ni}, \mathrm{As}, \mathrm{Mn}$, and $\mathrm{Hg}$ ) have been taken into account.

The HPI index represents the composite influence of heavy metals on the overall quality of water. The HPI is a method of assigning a rating or weighting $\left(W_{i}\right)$ for each chosen parameter and selecting the pollution parameter on which the index is to be based. The rating is a value between zero and one, reflecting the relative importance of individual quality considerations and defined as inversely proposal to the recommended standard for each heavy metal. Water quality and its suitability for drinking can be examined by determining its quality index (Mohan et al. 1996; Prasad and Kumari 2008; Ehya and Marbouti 2016). For this study, the concentration limits (i.e., maximum admissible concentration for drinking water (MAC), highest permissive value for drinking water $\left(S_{i}\right)$ and the maximum desirable value $\left(I_{i}\right)$ for each heavy metal) were taken from the international WHO standard. The HPI index can be calculated as Eq. 3 (Mohan et al. 1996): 
$\mathrm{HPI}=\frac{\sum_{i=1}^{n} W_{i} Q_{i}}{\sum_{i=1}^{n} W_{i}}$,

where $Q_{i}$ is the sub-index of the $i$ the parameter, $W_{i}$ is the unit weighting of the $i$ the parameter and $n$ is the number of parameters considered. The sub-index $\left(Q_{i}\right)$ of the parameter is calculated by Eq. 4:

$Q_{i}=\sum_{i=1}^{n} \frac{\left|M_{i}-I_{i}\right|}{S_{i}-I_{i}} \times 100$,

where $M_{i}$ is the monitored value of the $i$ th parameter, $I_{i}$ is the ideal value of $i$ th parameter, and $S_{i}$ the standard value for the $i$ th parameter.

In the study area, the median of HPI was 18.03 (Table 2), which is below the critical value of 100 . The maximum and minimum value of HPI are 41.5, 3.1, respectively. The results show that groundwater of study area are not contaminated with heavy metals.

The HEI index gives an overall quality of the water with respect to heavy metal content. The HEI is computed as Eq. 5:

$\mathrm{HEI}=\sum_{i=1}^{n} \frac{H_{c}}{H_{\mathrm{mac}}}$

where $H_{c}$ is the monitored value of the $i$ th parameter and $H_{\text {mac }}$ the maximum admissible concentration of the $i$ th parameter (Edet and Offiong 2002).

The median of HEI was 0.0013 (Table 2), which is below the critical value so that groundwater of study area is not contaminated with heavy metals.

\section{Drinking and irrigation water quality}

The analytical results have been evaluated to ascertain the suitability of groundwater of the study area for drinking and agricultural uses. The drinking water quality is evaluated by comparing with the specifications of TH and TDS set by the WHO (2004). According to WHO (2004) specification TDS up to $500 \mathrm{mg} / \mathrm{l}$ is the highest desirable and up to $1500 \mathrm{mg} / \mathrm{l}$ is maximum permissible (Table 3). Based on this classification, $92 \%$ of samples belongs to maximum permissible category and remaining samples are exceeding the maximum allowable limits. Maximum allowable limit of $\mathrm{TH}$ for drinking is $500 \mathrm{mg} / \mathrm{l}$ and the most desirable limit is $100 \mathrm{mg} / \mathrm{l}$ as per the WHO international standard. Based on this classification, it indicates that $40 \%$ of the samples exceed the maximum allowable limits; such water cannot be used for domestic purposes, because it coagulates soap lather.

The development and maintenance of successful irrigation projects involve not only the supplying of irrigation water to the land but also the control of salt and alkali in the soil (Haritash et al. 2008; Li et al. 2016). Salinity and indexes such as, sodium absorption ratio (SAR), sodium percentage $(\% \mathrm{Na})$, residual sodium carbonate (RSC), and permeability index (PI) are important parameters for determining the suitability of groundwater for agricultural uses (Srinivasa 2005; Raju 2007; Kord et al. 2013).

Electrical conductivity is a good measure of salinity hazard to crops as it reflects the TDS in groundwater. The Wilcox (1955) classified ground waters on the basis of electrical conductivity (Table 3). Based on this classification, $\% 22$ of samples belongs to the good category; $\% 70$ of samples belongs to the permissible category and $\% 8$ doubtful categories. Stuyfzand (1989) classified water on the basis of $\mathrm{Cl}^{-}$ion concentration into eight divisions as shown in Table 3. Based on this classification, $\% 13$ of groundwater samples were very fresh, $\% 38$ fresh, $\% 40$ fresh-brackish and $\% 9$ were brackish on the basis of $\mathrm{Cl}^{-}$concentration.

Sodium adsorption ratio (SAR) is an important parameter for determining the suitability of groundwater for irrigation because it is a measure of alkali/sodium hazard to crops (Subramani et al. 2005). SAR is defined by Karanth (1987) as Eq. 6

$\mathrm{SAR}=\frac{\mathrm{Na}^{+}}{\sqrt{\frac{\mathrm{Ca}^{2+}+\mathrm{Mg}^{2+}}{2}}}$,

Table 2 HPI calculation for median groundwater concentration (in $\mu \mathrm{g} / \mathrm{l}$ )

\begin{tabular}{llrrrrr}
\hline Heavy metals & $M_{i}$ & \multicolumn{1}{c}{$S_{i}$} & \multicolumn{1}{c}{$I_{i}$} & MAC & Sub. index $\left(Q_{i}\right)$ & Unit weightage $\left(W_{i}\right)$ \\
\hline $\mathrm{As}$ & 0.15 & 50 & 10 & 50 & 24.63 & 0.02 \\
$\mathrm{Cr}$ & 0 & 50 & 10 & 50 & 25 & 0.02 \\
$\mathrm{Cu}$ & 1.48 & 1500 & 50 & 1000 & 3.346 & 0.001 \\
$\mathrm{Hg}$ & 0.17 & 6 & 1 & 1 & 16.6 & 1 \\
$\mathrm{Mn}$ & 4.95 & 300 & 100 & 300 & 47.52 & 0.003 \\
$\mathrm{Ni}$ & 0.21 & 70 & 20 & 20 & 39.58 & 0.05 \\
$\mathrm{Zn}$ & 1.54 & 15000 & 5000 & 5000 & 49.99 & 0.0002 \\
\hline
\end{tabular}

$\sum W_{i}=1.0945 ; \sum W_{i} Q_{i}=19.74 ; \mathrm{HPI}=18.04, M$ median concentration value, $n=77 S$ highest permissive value, $I$ maximum desirable value, $M A C$ maximum admissible concentration 
Table 3 Classification of groundwater based on total hardness (TH), electrical conductivity (EC), chloride concentration, Sodium adsorption ratio (SAR), sodium percent $(\% \mathrm{Na})$ and residual sodium carbonate (RSC)

\begin{tabular}{|c|c|c|c|}
\hline Classification scheme & Categories & Ranges & Percent of samples \\
\hline \multirow[t]{4}{*}{ TH (Sawyer and Mccarty 1967) } & Soft & $<75$ & 2 \\
\hline & Moderately hard & $75-150$ & 10 \\
\hline & Hard & $150-300$ & 23 \\
\hline & Very hard & $>300$ & 65 \\
\hline \multirow[t]{5}{*}{ EC (Wilcox 1955) } & Excellent & $<250$ & - \\
\hline & Good & $250-750$ & 22 \\
\hline & Permissible & $750-2250$ & 70 \\
\hline & Doubtful & $2250-5000$ & 8 \\
\hline & Unsuitable & $>5000$ & - \\
\hline \multirow[t]{8}{*}{$\mathrm{Cl}^{-}$classification (Stuyfzand 1989) } & Extremely fresh & $<0.14$ & - \\
\hline & Very fresh & $0.14-0.85$ & 13 \\
\hline & Fresh & $0.85-4.23$ & 38 \\
\hline & Fresh brackish & $4.23-8.46$ & 40 \\
\hline & Brackish & $8.46-28.21$ & 9 \\
\hline & Brackish-salt & $28.21-282.06$ & - \\
\hline & Salt & $282.06-564.13$ & - \\
\hline & Hypersaline & $>564.13$ & - \\
\hline \multirow[t]{4}{*}{ SAR (Richards 1954) } & Excellent & $<10$ & 100 \\
\hline & Good & $10-18$ & - \\
\hline & Doubtful & $18-26$ & - \\
\hline & Unsuitable & $>26$ & - \\
\hline \multirow[t]{5}{*}{$\mathrm{Na} \%$ (Wilcox 1955) } & Excellent & $0-20$ & 13 \\
\hline & Good & $20-40$ & 35 \\
\hline & Permissible & $40-60$ & 34 \\
\hline & Doubtful & $60-80$ & 17 \\
\hline & Unsuitable & $>80$ & 1 \\
\hline \multirow[t]{3}{*}{ RSC (Richards 1954) } & Good & $<1.25$ & 88 \\
\hline & Medium & $1.25-2.5$ & 3 \\
\hline & Bad & $>2.5$ & 9 \\
\hline
\end{tabular}

where all ionic concentrations are expressed in meq/l. The SAR values range from 0.22 to 6.1 . According to the Richards (1954) classification based on SAR values (Table 3), all of samples belong to the excellent category. Sodium replacing adsorbed calcium and magnesium is a hazard as it causes damage to the soil structure and becomes compact and impervious (Raju 2007; Hosseinifard and Mirzaei Aminiyan 2015). The sodium percent $(\% \mathrm{Na})$ is obtained by the Eq. 7

$\mathrm{Na} \%=\frac{\left(\mathrm{Na}^{+}+\mathrm{K}^{+}\right) \times 100}{\left(\mathrm{Ca}^{2+}+\mathrm{Mg}^{2+}+\mathrm{Na}^{+}+\mathrm{K}^{+}\right)}$,

where all ionic concentrations are expressed in meq/l, according to the Wilcox (1955) classification based on $\% \mathrm{Na}$ values (Table 3), \%13 of samples belong to the excellent category, $\% 35$ of samples good category, $\% 34$ permissible category, $\% 17$ doubtful category and the remaining samples belong to the unsuitable category. High concentrations of $\mathrm{Na}$ are undesirable in water due to adsorption of $\mathrm{Na}$ onto the soil cation exchange sites, dispersion of soil aggregates, and reduction of soil permeability (Pazand and Javanshir 2014; Sethy et al. 2016; Golchin and Azhdary Moghaddam 2016). The excess sum of carbonate and bicarbonate amounts in groundwater over the sum of calcium and magnesium amounts also influences the unsuitability for irrigation (Aghazadeh and Mogaddam 2010; Hosseinifard and Mirzaei Aminiyan 2015; Sarikhani et al. 2015).

Residual sodium carbonate (RSC) has been calculated by the Eq. 8

$\mathrm{RSC}=\left(\mathrm{HCO}_{3}^{-}+\mathrm{CO}_{3}^{2-}\right)-\left(\mathrm{Ca}^{2+}+\mathrm{Mg}^{2+}\right)$,

where all ionic concentrations are expressed in meq/l (Eaton 1950). The classification of irrigation water according to the RSC values in waters containing more than $2.5 \mathrm{meq} / \mathrm{l}$ of RSC are not suitable for irrigation, while 
those having 1.25-2.5 meq/l are doubtful and those with less than $1.25 \mathrm{meq} / \mathrm{l}$ are good for irrigation-n (Richards 1954) (Table 3). Based on this classification, \%88 samples belong to the good category, $\% 3$ samples belong to the doubtful category and $\% 9$ belongs to unsuitable category.

The permeability index (PI) values are also used to determine for irrigation water quality. It is defined as Eq. 9

$\mathrm{PI}=\frac{\mathrm{Na}+\sqrt{\mathrm{HCO}_{3}}}{\mathrm{Ca}+\mathrm{Mg}+\mathrm{Na}} \times 100$,

where all the ions are expressed in meq/l (Ragunath 1987). WHO (1989) uses a criterion for assessing the suitability of water for irrigation based on permeability index. According to PI values, the groundwater of the study area can be designated as class II $(25-75 \%)$ indicate that the $88 \%$ of groundwater is suitable for irrigation excepting the $12 \%$ samples, which is classified as class I $(>75 \%)$.

\section{Industrial water quality}

The quality requirements for industrial water supplies range widely and almost every industrial unit has its own standards. Industries frequently suffer from the common undesirable effects of incrustation and corrosion, which the chemical reactions are caused by inferior water quality. In this study, we used Langelier saturation index (LSI), Ryznar stability index (RSI) Larson-Skold index (L-S index) and Puckorius scaling index (PSI) for determines the corrosive and scaling ability of water samples.

Langelier saturation index (Langelier 1936) is a system for estimating or predicting the amount or degree of problems with lime scale, caused in a particular water supply as it determines the corrosive or incrusting ability of a water sample.

The positive value of LSI indicates that the water is over or super saturated, depositing $\mathrm{CaCO}_{3}$ on the surface of metal and corrosion rates will be negligible. A negative index indicates that the water is under-saturated dissolving $\mathrm{CaCO}_{3}$ and will be considered as corrosive. The value close to zero states that the water is at saturation (equilibrium). Langelier saturation index is calculated by Eq. 10 (Kumar et al. 2009).

$\mathrm{LSI}=\mathrm{pH}-\mathrm{pH}_{(S)}$.

The saturation $\mathrm{pH}$ can be calculated as Eq. 11 (Davil et al. 2009):

$\mathrm{pH}_{(\mathrm{S})}=(9.3+a+b)-(c+d)$

$a=\frac{\left(\log _{10}[T D S]-1\right)}{10}$

$b=-13.12 \log _{10}\left({ }^{\circ} \mathrm{C}+273\right)+34.55$

$c=\log _{10}\left(\mathrm{Ca}^{2+}\right.$ as $\left.\mathrm{CaCO}_{3}, \mathrm{mg} / \mathrm{L}\right)-0.4$ $d=\log _{10}\left(\right.$ alkanity as $\left.\mathrm{CaCO}_{3}, \mathrm{mg} / \mathrm{L}\right)$.

Calculate the LSI value for groundwater samples in the study area indicated that $18.2 \%$ of the groundwater samples are supersaturated containing positive LSI index with a tendency to deposit $\mathrm{CaCO}_{3}$ and $81.8 \%$ of the groundwater samples are under-saturated containing negative LSI index, accounts for its slight corrosive nature with a tendency to dissolve $\mathrm{CaCO}_{3}$ as a result of low alkalinity and high free $\mathrm{CO}_{2}$ content (Sivasankar and Ramachandramoorthy 2009). The LSI values are given in Table 4 and illustrated through histograms (Fig. 10).

Ryznar (1944) has designed an empirical method to determine stability index for predicting scaling tendencies of water.

This index can be calculated like LSI as follows Eq. 16 (Kannan 1991; Ravikumar and Somashekar 2012):

$\mathrm{RSI}=2 \mathrm{pH}_{(\mathrm{S})}-\mathrm{pH}$

The result indicates that $53.2 \%$ of the samples are classified into aggressive category and $45.5 \%$ of the samples are classified into very aggressive category. Only one sample exhibits no scale forming tendency (Table 4; Fig. 11).

Larson-Skold index (L-S) is the ratio of sulfate and chloride to the alkalinity in the form of bicarbonate and carbonate (Jevaprabha et al. 2006; Ravikumar and Somashekar 2012). The L-S index can be calculated by Eq. 16 (Larson and Skold 1958).

$\mathrm{L}-\mathrm{S}$ index $=\frac{\left(\mathrm{SO}_{4}^{2-}+\mathrm{Cl}^{-}\right)}{\left(\mathrm{HCO}_{3}^{-}-\mathrm{CO}_{3}^{2-}\right)}$.

The value of L-S index below 0.8 indicates that chloride and sulfate do not interfere with natural inhibitor film formation while the value greater than 1.2 states the tendency towards high corrosion. The value of L-S index between 0.8 and 1.2 indicates that these ions may interfere with natural film formations (Rabbani et al. 2008). In the study area, chloride and sulfate interfere in $62.3 \%$ of the samples, do not interfere with natural film formation in $15.58 \%$ of the samples and may interfere with natural film formation in $22 \%$ of the samples (Table 4; Fig. 11).

The Puckorius scaling index (PSI) is used to account the buffering capacity and the maximum quantity of precipitation that can form in bringing water to equilibrium (Davil et al. 2009).

The PSI index is calculated in a manner similar to the Ryznar stability index, Puckorius has used an equilibrium $\mathrm{pH}$ rather than the actual system $\mathrm{pH}$ to account for the buffering effects. Conveniently, the PSI uses the same numbering systems and general interpretation as does the RSI (Sargaonkar and Deshpande 2003; Ravikumar and Somashekar 2012). 
Table 4 LSI, RSI, L-S, and PSI index values of water samples in Ardabil plain

\begin{tabular}{|c|c|c|c|c|}
\hline Parameters & Range & Indication & No. of samples & $\overline{\text { Percent }}$ \\
\hline \multirow[t]{3}{*}{ LSI (saturation capacity) } & $<0$ & $\begin{array}{l}\text { Waters under-saturated with respect to } \mathrm{CaCO}_{3} \text { and has a tendency } \\
\text { to remove existing } \mathrm{CaCO}_{3} \text { protective coatings in pipelines and equipment }\end{array}$ & 63 & 81.8 \\
\hline & 0 & $\begin{array}{l}\text { Water is saturated (in equilibrium) with } \mathrm{CaCO}_{3} \text {. A scale layer of } \mathrm{CaCO}_{3} \\
\text { is neither precipitated nor dissolved }\end{array}$ & - & - \\
\hline & $>0$ & $\begin{array}{l}\text { Water is supersaturated with respect to } \mathrm{CaCO}_{3} \text { and scale } \\
\text { forming may occur }\end{array}$ & 14 & 18.2 \\
\hline \multirow[t]{5}{*}{ RSI (scaling capacity) } & $<5.5$ & Heavy & - & - \\
\hline & $5.5-6.2$ & Scale & - & - \\
\hline & $6.2-6.8$ & No scale & 1 & 1.3 \\
\hline & $6.8-8.5$ & Aggressive & 41 & 53.2 \\
\hline & $>8.5$ & Very aggressive & 35 & 45.5 \\
\hline \multirow{3}{*}{$\begin{array}{l}\text { L-SI index (interference } \\
\text { of } \mathrm{Cl} \text { and } \mathrm{SO}_{4} \text { ) }\end{array}$} & $<0.8$ & Not interfere & 12 & 15.58 \\
\hline & $0.8-1.2$ & May interfere & 17 & 22 \\
\hline & $>1.2$ & Interfere & 48 & 62.3 \\
\hline \multirow[t]{5}{*}{ PSI (scaling capacity) } & $<5.5$ & Heavy & 2 & 2.6 \\
\hline & $5.5-6.2$ & Scale & 13 & 16.9 \\
\hline & $6.2-6.8$ & No scale & 15 & 19.5 \\
\hline & $6.8-8.5$ & Aggressive & 24 & 31.1 \\
\hline & $>8.5$ & Very aggressive & 23 & 29.9 \\
\hline
\end{tabular}

Fig. 10 Evaluation of LSI for the groundwater samples in the study area

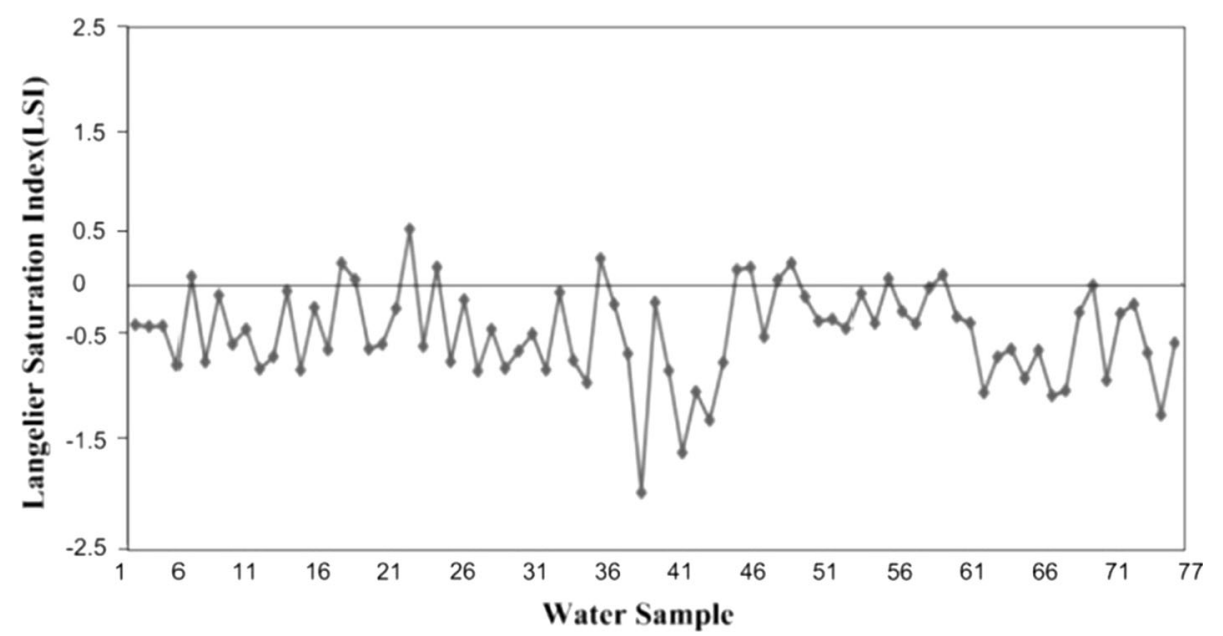

$\mathrm{PSI}=2 \mathrm{pH}_{(S)}-\mathrm{pH}_{\mathrm{eq}}$.

The result indicated that $2.6 \%$ of the samples are classified into heavy category, $16.9 \%$ scale category, $19.5 \%$ no scale category, $16.9 \%$ aggressive category and $62.3 \%$ very aggressive category (Table 4; Fig. 11).

\section{Conclusions}

In the most groundwater samples of study area no cationanion exceeding 50\%, however the major cations are $\mathrm{Ca}^{2+}$, $\mathrm{Na}^{+}$and the anions are $\mathrm{HCO}_{3}{ }^{-}, \mathrm{Cl}^{-}$. In the study area, the dominant water types are $\mathrm{Ca}, \mathrm{Mg}-\mathrm{HCO}_{3}, \mathrm{Na}-\mathrm{HCO}_{3}$ and $\mathrm{Na}-\mathrm{Cl}$. Results from the chemical analyses and minerals saturation index shows that chemical properties of groundwater in study area are controlled by natural geochemical processes such as mineral weathering, mixing, ion exchange and anthropogenic activities. Calculate the HPI and HEI heavy metal indices for determining the contamination of groundwater samples in the study area indicated that the groundwater of study area are not contaminated with heavy metals. Assessment of water samples according to exceeding the permissible limits prescribed by WHO standard for drinking purposes indicated that most of the groundwater in study area is chemically suitable for 


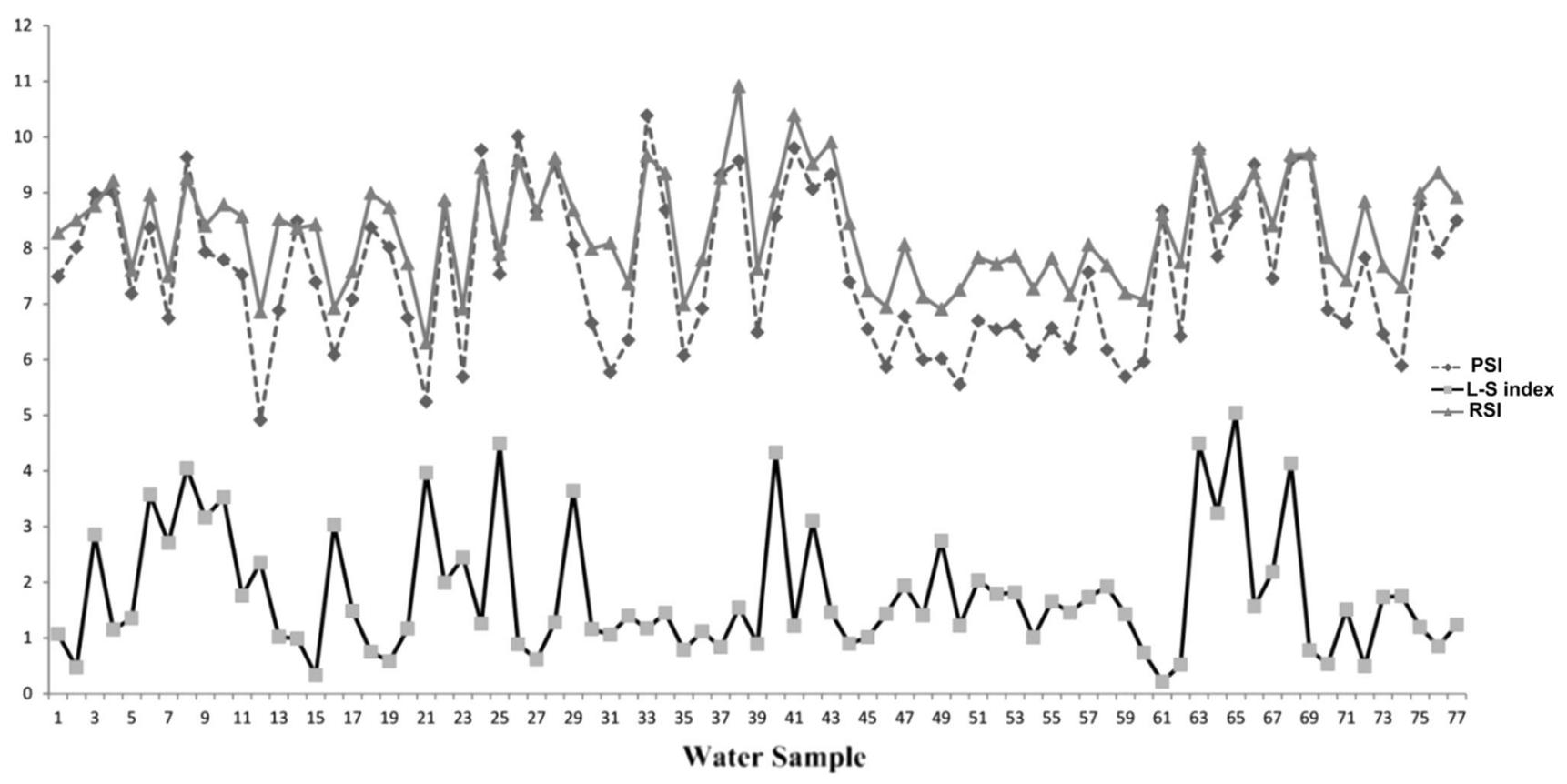

Fig. 11 Evaluation of RSI, L-S and PSI index for the groundwater samples in the study area

drinking uses. The suitability of groundwater for irrigation use was assessed from EC, SAR, RSC, $\mathrm{Na} \%$, and PI which varies from good to permissible, and indicated that most of the samples are suitable for this purpose. Calculating the LSI, RSI, L-S and PSI indices for determining the industrial water quality and the corrosive and scaling ability of groundwater samples in the study area indicated that most of the samples are corrosive and classified into aggressive category.

Acknowledgements The authors gratefully acknowledge the Environmental Protection Agencies of Iran, Urmia Golroud Consulting Engineers and Ardabil Regional Water Authority for supplying the existing relevant data and also wish to thank Dr. Ariyanfar for their kindly help during in this study.

Open Access This article is distributed under the terms of the Creative Commons Attribution 4.0 International License (http:// creativecommons.org/licenses/by/4.0/), which permits unrestricted use, distribution, and reproduction in any medium, provided you give appropriate credit to the original author(s) and the source, provide a link to the Creative Commons license, and indicate if changes were made.

\section{References}

Aghazadeh N, Mogaddam AA (2010) Investigation of hydrochemical characteristics of groundwater in the Harzandat aquifer Northwest of Iran. Environ Monit Assess 176:183-195

Aly AA (2015) Hydrochemical characteristics of Egypt western desert oases groundwater. Arab J Geosci 8:7551-7564
APHA (1995) Standard methods for the examination of water and wastewater 19th edn. American Public Health Association, Washington, pp 1-467

Appelo CAJ, Postma D (1996) Geochemistry groundwater and pollution. Balkema, Rotterdam, p 536

Ardabil Regional Water Authority (ARWA) (2014) Evaluation of groundwater in Ardabil plain. Ardabil Regional Water Authority, Ardabil

Asghari Moghaddam A, Najib A (2006) Hydrogeologic characteristics of the alluvial tuff aquifer of northern Sahand Mountain slopes Tabriz Iran. Hydrogeol J 14:1319-1329

Ayenew T, Demlie M, Wohnlich S (2008) Hydrogeological framework and occurrence of groundwater in the Ethiopian aquifers. J Afr Earth Sci 52:97-113

Back W (1966) Hydrochemical facies and groundwater flow patterns in the northern part of the Atlantic Coastal Plain. USGS. Paper 498-A

Barzegar R, Moghaddam AA, Najib M, Kazemian N, Adamowski J (2016) Characterization of hydrogeologic properties of the Tabriz plain multilayer aquifer system, NW Iran. Arab J Geosci 9:147

Cao Y, Tang C, Song X, Liu C, Zhang Y (2016) Identifying the hydrochemical characteristics of rivers and groundwater by multivariate statistical analysis in the Sanjiang Plain, China. Appl Water Sci 6:169-178

Chukwura UO, Udom GJ, Cuthbert SJ, Hursthouse AS (2015) Evaluation of hydrochemical characteristics and flow directions of groundwater quality in Udi Local Government Area Enugu State, Nigeria. Environ Earth Sci 73:4541-4555

Coetsiers M, Walraevens K (2006) Chemical characterization of the Neogene Aquifer Belgium. Hydrogeol J 14:1556-1568

Davil MF, Mahvi AH, Norouzi M, Mazloomi S, Amarluie A, Tardast A, Karamitabar Y (2009) Survey of corrosion and scaling potential produced water from IIam water treatment plant. World Appl Sci J 7:01-06

Domenico PA, Schwartz FW (1990) Physical and chemical hydrogeology. Wiley, New York, p 824 
Drever JI (1997) The Geochemistry of natural waters. Prentice-Hall, New Jersey, p 436

Durov SA (1948) Natural waters and graphical representation of their composition. Dokl Akad Nauk SSSR 59:87-90

Eaton FM (1950) Significance of carbonate in irrigation water. Soil Sci 69(2):123-133

Edet AE, Offiong OE (2002) Evaluation of water quality pollution indices for heavy metal contamination monitoring. A study case from Akpabuyo-Odukpaniarea Lower Cross River Basin (Southeastern Nigeria). Geo J 57:295-304

Ehya F, Marbouti Z (2016) Hydrochemistry and contamination of groundwater resources in the Behbahan plain, SW Iran. Environ Earth Sci 75:455

Esmaeili V, Rasa M, Amiri IV, Yazdi M, Pazand K (2015) Evaluation of groundwater quality and assessment of scaling potential and corrosiveness of water samples in Kadkan aquifer Khorasan-eRazavi Province Iran. Environ Monit Assess 187:53

Fijani F, Moghaddam AA, Tsai FTC, Tayfur G (2016) Analysis and Assessment of Hydrochemical Characteristics of MaraghehBonab Plain Aquifer. Water Resour Manage, Northwest of Iran. doi:10.1007/s11269-016-1390-y

Fisher RS, Mullican FW (1997) Hydrochemical evolution of sodiumsulfate and sodium-chloride groundwater beneath the Northern Chihuahuan Desert Trans- Pecos Texas USA. Hydrogeol J 10(4):455-547

Freeze RA, Cherry JA (1979) Groundwater. Prentice-Hall Englewood Cliffs, New Jersey

Garrels R, Mackenzie F (1967) Origin of the chemical compositions of some springs and lakes. In: Ground RF (ed) Equilibrium concepts in natural water systems. American Chemical Society Publications, Washington

Gibbs RJ (1970) Mechanisms controlling world water chemistry. Science 17:1088-1090

Giridharan L, Venugopal T, Jayaprakash M (2008) Evaluation of the seasonal variation on the geochemical parameters and quality assessment of the groundwater in the proximity of River Cooum Chennai India. Environ Monit Assess 143:161-178

Golchin I, Azhdary Moghaddam M (2016) Hydro-geochemical characteristics and groundwater quality assessment in Iranshahr plain aquifer, Iran. Environ Earth Sci 75:317

Guler C, Thyne GD (2004) Hydrologic and geologic factors controlling surface and groundwater chemistry in Indian Wells-Owens Valley area southeastern California USA. J Hydrol 285:177-198

Han D, Liang X, Jin M, Currell MJ, Han Y, Song X (2009) Hydrogeochemical indicators of groundwater flow systems in the Yangwu River Alluvial Fan Xinzhou Basin Shanxi China. Environ Manag 44:243-255

Haritash AK, Kaushik CP, Kaushik A, Kansal A, Yadav AK (2008) Suitability assessment of groundwater for drinking irrigation and industrial use in some North Indian villages. Environ Monit Assess 145:397-408

Hosseinifard SJ, Mirzaei Aminiyan M (2015) Hydrochemical characterization of groundwater quality for drinking and agricultural purposes: a case study in Rafsanjan plain, Iran. Water Qual Expo Health 7:531-544

Jalali M (2007) Hydrochemical identification of groundwater resources and their changes under the impacts of human activity in the Chah basin in western Iran. Environ Monit Assess 1(30):347-436

Jevaprabha C, Sathiyanarayanan S, Muralidharam S, Venkatachari G (2006) Corrosion inhibition of iron in $0.5 \mathrm{~mol} \mathrm{~L}-1 \mathrm{H}_{2} \mathrm{SO}_{4}$ by halide ions. J Braz Chem Soc 17:61-67

Kannan K (1991) Fundamentals of environmental pollution. Chand and company limited, New Delhi
Karanth KR (1987) Groundwater assessment development and management. Tata McGraw Hill, New Delhi, p p720

Kavurmac M, Ustun AK (2016) Assessment of groundwater quality using DEA and AHP: a case study in the Sereflikochisar region in Turkey. Environ Monit Assess 188:258

Khazaei E, Stednick JD, Sanford WE, Warner JW (2006) Hydrochemical changes over time in the Zahedan aquifer Iran. Environ Monit Assess 114:123-143

Kord M, Moghaddam AA, Nakhaeei M (2013) Assessment of Ground Water Quality for Irrigation in Ardabil Plain. Int J Agric Crop Sci 5-18:2135-2140

Kumar H, Saini V, Kumar D, Chaudhary RS (2009) Influence of trisodium phosphate (TSP) anti-salant on the corrosion of carbon steel in cooling water systems. Indian $\mathbf{J}$ Chem Technol $16: 401-410$

Langelier WF (1936) The analytical control of anti-corrosion water treatment. Am Water Works Assoc 28:1500-1521

Langmuir D (1997) Aqueous environmental geochemistry. Prentice Hall Inc, Upper Saddle River, p 601

Larson TE, Skold RV (1958) Laboratory studies relating mineral water quality of water on corrosion of steel and cast iron. Corrosion 14:285-288

Li P (2016) Groundwater quality in Western China: challenges and paths forward for groundwater quality research in Western China. Expo Health 8:305-310

Li P, Wu J, Qian H (2016) Hydrochemical appraisal of groundwater quality for drinking and irrigation purposes and the major influencing factors: a case study in and around Hua County China. Arab J Geosci 9:15

Lloyd JW, Heathcode JA (1985) Natural inorganic hydrochemistry in relation to groundwater. Oxford University Press, New York

Mohan SV, Nithila P, Reddy SJ (1996) Estimation of heavy metal in drinking water and development of heavy metal pollution index. J Environ Sci Health 31(2):283-289

Nabavi MH (1976) Preface geology of Iran. Geology Survey Iran, Tehran

Parkhurst DL, Appelo CAJ (1999) User's guide to PHREEQC (ver. 2): A computer program for speciation batch-reaction onedimensional transport and inverse geochemical calculations. US Geo Surv Water Resour Invest Rept pp 99-4259

Pazand K, Javanshir A (2014) Geochemistry and Water Quality Assessment of Groundwater around Mohammad Abad Area, Bam District, SE Iran. Water Qual Expo Health 6:225-231

Piper AM (1944) A graphic procedure in the geochemical interpretation of water analysis. Am Geophys Union Transplant 25:914-928

Prasad B, Bose JM (2001) Evaluation of heavy metal pollution index for surface and spring water near a limestone mining area of the lower Himalayas. Environ Geol 41:183-188

Prasad B, Kumari S (2008) Heavy metal pollution index of ground water of an abandoned open cast mine filled with fly ash: a case study. Mine Water Environ 27(4):265-267

Rabbani D, Mirranzadeh MB, Motlagh AA (2008) Study for determination of industrial water corrosivity in KashanFajreSepahan galvanizing mills during 2005-2006 Iran. Pak J Biol Sci 11:131-134

Ragunath HM (1987) Groundwater. Wiley Eastern Ltd, New Delhi, p p563

Raju NJ (2007) Hydrogeochemical parameters for assessment of groundwater quality in the upper Gunjanaeru River basin Cuddapah District Andhara Pradesh South India. Environ Geol 52:1067-1074

Ravikumar P, Somashekar RK (2012) Assessment and modeling of groundwater quality data and evaluation of their corrosiveness and scaling potential using environ metric methods in Bangalore South Taluk Karnataka State India. Water Resour 39:446-473 
Richards LA (1954). Diagnosis and improvement of saline alkali soils: Agriculture (vole 160. Handbook 60). US Department of Agriculture, Washington

Ryznar JW (1944) A new index for determining amount of calcium carbonate scale formed by water. Am Water Works Assoc 36:472-486

Sargaonkar A, Deshpande V (2003) Development of an overall index of pollution for surface water based on a general classification scheme in Indian context. Environ Monit Assess 89:43-67

Sarikhani R, Ghassemi Dehnavi A, Ahmadnejad Z, Kalantari N (2015) Hydrochemical characteristics and groundwater quality assessment in Bushehr Province, SW Iran. Environ Earth Sci 74:6265-6281

Sawyer CN, Mccarty PL (1967) Chemistry for environmental engineering. Mc-Graw Hill, p 532

Sethy SN, Syed TH, Kumar A, Sinha D (2016) Hydrogeochemical characterization and quality assessment of groundwater in parts of Southern Gangetic Plain. Environ Earth Sci 75:232

Jacintha TGA, Rawat KS, Mishra A, Singh, SK (2016) Hydrogeochemical characterization of groundwater of peninsular Indian region using multivariate statistical techniques. Appl Water Sci doi:10.1007/s13201-016-0400-9

Singh AK, Mondal GC, Singh TB, Singh S, Tewary BK, Sinha A (2012) Hydrogeochemical processes and quality assessment of groundwater in Dumka and Jamtara districts, Jharkhand, India. Environ Earth Sci 67:2175-2191

Sivasankar V, Ramachandramoorthy T (2009) An investigation on the pollution status of holy aquifers of Rameswaram Tamil Nadu India. Environ Monit Assess 156:307-315

Srinivasa GS (2005) Assessment of groundwater quality for drinking and irrigation purpose: a case study of Peddavanka watershed
Anantapur District Andhra Pradesh India. Environ Geol 48:702-712

Srivastava SK, Ramanathan AL (2008) Geochemical assessment of groundwater quality in vicinity of Bhalswa landfill Delhi India using graphical and multivariate statistical methods. Environ Geol 53:1509-1528

Stuyfzand PJ (1989) Nonpoint source of trace element in potable groundwater in Netherland. In: Proceedings of the 18th TWSA Water Working, Testing and Research Institute KIWA, Nieuwegein

Subramani T, Elango L, Damodarasamy SR (2005) Groundwater quality and its suitability for drinking and agricultural use in Chithar River Basin Tamil Nadu India. Environ Geol 47:1099-1110

Umar A, Umar R, Ahmad MS (2001) Hdrogeological and hydrochemical framework of regional aquifer system in KaliGanga sub-basin India. Environ Geol 40(4-5):602-661

Vincy MV, Brilliant R, Pradeepkumar AP (2015) Hydrochemical characterization and quality assessment of groundwater for drinking and irrigation purposes: a case study of Meenachil River Basin Western Ghats Kerala, India. Environ Monit Assess $187: 4217$

WHO (1989) Health Guidelines for the use of wastewater in Agriculture and Aquaculture. Report of a WHO Scientific Group-Technical Report Series 778, World Health Organization, Geneva, p 74

WHO (2004) Guidelines for drinking water quality. World Health Organization, Geneva

Wilcox LV (1955) Classification and use of irrigation water (Circular 969). USDA, Washington 